\title{
The impact of ploughing and zero tillage soil cultivation on species diversity of ground-dwelling spiders in the cultivation of winter rape
}

\section{Wpływ orkowej i bezorkowej uprawy gleby na różnorodność gatunkową epigeicznych pająków w uprawie rzepaku ozimego}

\author{
Elżbieta Topa*
}

\begin{abstract}
Summary
The research aimed to evaluate the effect of ploughing and zero tillage soil cultivation on the species diversity of ground-dwelling spiders inhabiting winter rape. During the two-year observation (2012-2013), a total of 887 spiders belonging to 12 families and 38 species were caught in rapeseed crops. Dominated in both soil cultivation variants were spiders of the Linyphiidae family with the most common species Oedothorax apicatus (Black.) and the Lycosidae family with its representative Pardosa agrestis (Westr.). The use of simplifications in the cultivation of winter rape in the form of zero tillage cultivation had a positive effect on both the abundance and species diversity of epigenous spiders.
\end{abstract}

Key words: soil tillage, biodiversity, ground-dwelling spiders, winter rape

\section{Streszczenie}

Celem badań była ocena wpływu orkowej i bezorkowej uprawy gleby na różnorodność gatunkową naziemnych pająków zasiedlających uprawy rzepaku ozimego. Podczas dwuletnich obserwacji (2012-2013) odłowiono w uprawach rzepaku łącznie 887 pająków należących do 12 rodzin i 38 gatunków. W obu wariantach uprawy gleby dominowały pająki z rodziny Linyphiidae z najczęściej występującym gatunkiem Oedothorax apicatus (Black.) oraz pająki z rodziny Lycosidae, z jej przedstawicielem Pardosa agrestis (Westr.). Stosowanie uproszczeń w uprawie rzepaku ozimego w postaci uprawy bezorkowej wpłynęło dodatnio zarówno na liczebność, jak i różnorodność gatunkową pająków epigeicznych.

Słowa kluczowe: system uprawy gleby, bioróżnorodność, pająki epigeiczne, rzepak ozimy

Uniwersytet Warmińsko-Mazurski w Olsztynie

Katedra Entomologii, Fitopatologii i Diagnostyki Molekularnej

Prawocheńskiego 17, 10-720 Olsztyn

*corresponding author: topa@uwm.edu.pl

ORCID: 0000-0002-4691-2051 


\section{Wstęp / Introduction}

Pająki Araneae obok chrząszczy z rodzin biegaczowatych i kusakowatych stanowią dominującą grupę drapieżnych bezkręgowców obserwowaną w różnych agrosystemach. Na polach uprawnych zagęszczenie pająków może być tak duże, że powierzchnia ich sieci może obejmować $50 \%$ powierzchni pola przez nie zajmowanego (Sunderland 1999), ilościowo natomiast może wahać się od kilku do kilkuset osobników na metr kwadratowy. Nie bez znaczenia są różne strategie polowań wśród pająków, które pozwalają wyróżnić aktywnie polujące pająki naziemne, aktywnie polujące pająki naroślinne oraz pająki sieciowe (Hänggi i wsp. 1995; Nyffeler i Sunderland 2003). Brak specjalizacji pokarmowej pająków uznaje się za potencjalny czynnik ograniczający pojaw wielu szkodników w uprawach rolniczych. Utrzymanie bioróżnorodności pająków w agrocenozach ma duże znaczenie w ograniczaniu występowania szkodników poniżej progów szkodliwości (Symondson i wsp. 2002; Nyffeler i Sunderland 2003). Szczególnie na początku sezonu wegetacyjnego, kiedy liczebność zespołu drapieżnych owadów jest niedostateczna (Entling i wsp. 2011; Gallé i wsp. 2018). W uprawach polowych pająki są ważną grupą stabilizującą liczebność fitofagów, szczególnie mszyc (Symondson i wsp. 2002; Nyffeler i Sunderland 2003; Büchs i wsp. 2007). Badania Öberg i wsp. (2011) wskazują, że w diecie pająków epigeicznych w uprawie rzepaku znalazły się larwy słodyszka rzepakowego - Meligethes aeneus (Fabr.), a Jõgar i wsp. (2004b) dodają do listy ofiar larwy pryszczarka kapustnika - Dasineura brassicae (Winn.)

Zastąpienie tradycyjnej uprawy roli systemami uproszczonymi dotyczy coraz większej grupy rolników posiadających duże gospodarstwa. Literatura traktująca o wpływie uproszczeń w uprawie gleby na faunę pożyteczną jest bardzo bogata, chociaż dotyczy w dużym zakresie drapieżnych chrząszczy (Holland i Reynolds 2003; Twardowski 2010; Kosewska 2016, 2018). Uproszczone systemy uprawy roli wpływają dodatnio na stabilność środowiska zwiększając bioróżnorodność gatunkową (Downie i wsp. 2000), natomiast wpływ upraw orkowych jest niejednoznaczny w stosunku do Araneae. Schmidt i wsp. (2005) wykazują dużą wrażliwość pająków na płużną uprawę roli, z drugiej strony Duffey (1978) wykazał, że orka nie miała wpływu na pająki $\mathrm{z}$ rodziny Linyphiidae.

Badania miały na celu ocenę wpływu orkowej i bezorkowej uprawy gleby na różnorodność gatunkową naziemnych pająków zasiedlających uprawy rzepaku ozimego.

\section{Materiały i metody / Materials and methods}

Badania prowadzono $\mathrm{w}$ województwie warmińsko-mazurskim w Tomaszkowie koło Olsztyna (GPS 53,718725; 20,414701). Obserwacje dotyczące epigeicznych pająków przeprowadzono w dwuletnim cyklu, w 2012 i 2013 roku. Sezon połowów miał charakter ciągły i realizowany był w obu latach badań od maja do końca lipca, w 12-dniowych odstępach (84 dni w 2012 roku, 83 dni w 2013 roku). Łącznie podczas dwuletnich badań dokonano po 14 obserwacji na każdej powierzchni. Podczas odłowów arachnofauny zastosowano metodę zmodyfikowanych pułapek Barbera (Barber 1931), wypełnionych w 1/3 roztworem glikolu etylenowego. Obserwacje entomologiczne prowadzono na polach rzepaku ozimego od fazy $60 \mathrm{BBCH}$ (początek kwitnienia) do fazy $92 \mathrm{BBCH}$ (zamieranie, do zbioru) z orkową (Or) (odmiana Visby F1) i bezorkową (Bor) (odmiana DK Exquisite) uprawą. W każdym systemie uprawy gleby wyznaczono po dwie powierzchnie badawcze, na których założono liniowo po 5 pułapek glebowych w 10 metrowych odstępach. Powierzchnie oddalone były od siebie o około 300 metrów.

Na powierzchni pod uprawę rzepaku z orką wykonano talerzowanie, orkę i bronowanie, a w bezorkowej talerzowanie, uprawę gruberem i bronowanie. W obu lokalizacjach siew wykonano w drugiej połowie sierpnia, a zabiegi regulacji pokroju i wzrostu roślin oraz ochrony przed szkodnikami i patogenami prowadzono terminowo zgodnie z zaleceniami Instytutu Ochrony Roślin - Państwowego Instytutu Badawczego w Poznaniu. Zbiór rzepaku ozimego przeprowadzono w 2012 roku 31. lipca, zaś w 2013 roku 30. lipca, każdorazowo dzień po ostatnim odłowie arachnofauny.

W obserwacjach epigeicznych pająków posłużono się metodą ilościową z uwzględnieniem liczby osobników, liczby gatunków oraz rodzin. Oznaczony materiał (Nentwig i wsp. 2020) zaklasyfikowano również do różnych grup ekologicznych na podstawie opracowania Hängii i wsp. (1995). Pod względem preferencji siedliskowych wyróżniono wśród nich pająki terenów otwartych, eurytopowe (generalistów) oraz leśne. Dodatkowo wyszczególniono gatunki szybko kolonizujące agrocenozy, tzw. agrobionty oraz gatunki budujące sieci. Przy opracowaniu wyników posłużono się wskaźnikami ogólnej różnorodności gatunkowej Shannona H' (Log Base 2,718) oraz równomierności Pielou (J'). $\mathrm{W}$ celu stwierdzenia istotności różnic w składzie gatunkowym, liczebności, wskaźnikach różnorodności oraz wybranych parametrach ekologicznych zgrupowań pająków w orkowej i bezorkowej uprawie rzepaku, ze względu na brak rozkładu normalnego, posłużono się uogólnionym modelem liniowym (GLM - General Linnear Model) dla rozkładów Poissona. Dodatkowo różnice w składzie gatunkowym i liczebności pająków dwóch badanych systemów uprawy gleby testowano za pomocą niemetrycznego skalowania wielowymiarowego (NMDS - non-metric multidimensional scaling), w którym jako wskaźnik podobieństwa użyto indeksu Bray-Curtisa, a istotność statystyczną potwierdzono za pomocą analizy wariancji podobieństwa (ANOSIM). Podczas analizy zgrupowań pająków uwzględniono tylko okazy oznaczone do gatunku. 


\section{Wyniki i dyskusja / Results and discussion}

Podczas dwuletnich obserwacji odłowiono w uprawach rzepaku łącznie 887 pająków należących do 12 rodzin i 38 gatunków (tab. 1). Podobne wyniki są podane w badaniach z terenu Austrii (Drapela i wsp. 2008), gdzie liczebność pająków w uprawach rzepaku wahała się od 201 do 760 osobników w przeliczeniu na pole. Büchs i wsp. (2007) wykazują tylko 25 gatunków Araneae, jako dominantów i subdominantów w uprawach rzepaku ozimego na terenie Europy. Porównywalne było też bogactwo gatunkowe. Ogólnie należy stwierdzić, że uprawy rzepaku ozimego charakteryzują się niskimi liczebnościami odławianych pająków, w porównaniu do innych upraw (Jõgar i wsp. 2004b; Piper i Williams 2004; Drapela i wsp. 2008).

Zarówno w roku 2012, jak i 2013, pod względem ilościowym pająki odłowione na obszarze bezorkowej uprawy rzepaku występowały liczniej niż w systemie płużnym. W systemie bezorkowym pozyskano w obu latach badań 503 osobniki, podczas gdy w systemie orkowym były to 384 osobniki. Najliczniejszą rodziną pająków podczas dwuletnich badań była rodzina Linyphiidae stanowiąca $86 \%$ odłowionego materiału, z dominującymi gatunkami Oedothorax apicatus (Black.), Erigone atra (Black.) i Erigone dentipalpis (Wider). Te budujące sieci, ale i aeronautyczne gatunki zawsze są licznie obserwowane na wszystkich uprawach polowych w Europie, gdzie stanowią około 40-90\% zespołu Araneae (Jõgar i wsp. 2004b; Drapela i wsp. 2008). Szczególnie gatunkowi E. atra sprzyjają uprawy rolnicze wysiewane jesienią, co dokładnie opisują Downie i wsp. (2000). Drugą dominującą rodziną była rodzina Lycosidae ( $8 \%$ zebranych osobników), najliczniejsza w bezorkowym systemie, zwłaszcza w 2012 roku. Te aktywnie polujące pająki nie budują sieci łownych, a na ofiarę czekają w ukryciu. Ich atutem jest dobry wzrok oraz duża ruchliwość i szybkość (Jõgar i wsp. 2004b). Na uwagę zasługuje agrobiontyczny gatunek Pardosa agrestis (Westr.) występujący w większości obszarów rolniczych w Europie, często dominujący w uprawach rzepaku i szeroko opisywany w badaniach dotyczących efektywności drapieżnictwa pająków (Samu i Szinetar 2002; Drapela i wsp. 2008; Frank i wsp. 2010; Drapela i wsp. 2011). Öberg i wsp. (2011), opierając się na badaniach DNA zawartości żołądków pająków z rodzaju Pardosa spp. wykazali wśród ofiar obecność larw słodyszka rzepakowego, które znalazły się na powierzchni gleby przed zapoczwarczeniem. Wskaźnik ogólnej różnorodności gatunkowej Shannona (H') oraz powiązany z nim wskaźnik równomierności Pielou (J'), niezależnie od roku badań osiągnęły wyższe wartości w bezorkowym systemie uprawy gleby, co świadczyć może o większej różnorodności gatunkowej pożytecznych bezkręgowców w tym systemie (tab. 1). Bioróżnorodność Lycosidae jest ściśle, dodatnio skorelowana z obecnością szaty roślinnej w postaci chwa- stów oraz niską intensywnością zabiegów insektycydowych w uprawach (Jõgar i wsp. 2004a). Wykazano także, że sąsiedztwo nieużytków i zadrzewień śródpolnych jest rezerwuarem pająków w okresach np. mechanicznej uprawy gleby i korzystnie kształtuje ich bioróżnorodność (Schmidt i wsp. 2005; Drapela i wsp. 2008; Topa i wsp. 2010; Gallé i wsp. 2018).

Analizując średnie liczby odłowionych osobników i gatunków, a także średnie wartości wskaźnika różnorodności gatunkowej (H') zaobserwowano statystycznie istotne różnice w dwóch badanych systemach uprawy gleby (tab. 2). W każdym z wymienionych przypadków średnie wartości były wyższe w uprawie bezorkowej (rys. 1a, b, c). Szczególnie znaczącą różnicę odnotowano w przypadku średniej liczby odłowionych gatunków (rys. 1b) oraz średnich wartości indeksu różnorodności gatunkowej Shannona (rys. 1c).

Biorąc pod uwagę charakterystykę ekologiczną odłowionych na polach pająków zaobserwowano, że sposób uprawy gleby wpływał istotnie na wszystkie wytypowane grupy, oprócz generalistów (tab. 2). Grupa ta cechowała się szerokim spektrum występowania niezależnie od sposobu uprawy gleby. Nietypową na polach grupą były pająki leśne, które pomimo, że wykazały preferencje w kierunku mało zakłócanej uprawy bezorkowej, wystąpiły na badanych polach w bardzo niewielkiej liczebności, dlatego też nie zostały wzięte pod uwagę w dalszych analizach. Najczęściej występujące na polach pająki terenów otwartych, grupujące pająki pól, łąk i nieużytków, chętniej wybierały bezorkową uprawę rzepaku (rys. 2a). Dodatkowo ze zbioru pająków wydzielono gatunki aeronautyczne, szczególnie szybko kolonizujące agrocenozy. Agrobionty również były wrażliwe na sposób uprawy gleby występując liczniej na polach bezorkowych (rys. 2b). Interesującą grupą pająków ze względu na strategie łowieckie są pająki sieciowe. To przedstawiciele dominującej na badanych polach rzepaku rodziny Linyphiidae. W wydzielonej grupie pająków sieciowych zaobserwowano istotny wpływ sposobu uprawy na ich średnią liczebność, która była znacząco wyższa na polach z bezorkową uprawą rzepaku (rys. 2c). Büchs i wsp. (2007) podają, iż płatowatym pajęczynom Linyphiidae w uprawie rzepaku ozimego wyraźnie sprzyjała uprawa w systemie integrowanym w stosunku do uprawy standardowej z uprawą płużną. Prawdopodobnie mniejsza ingerencja człowieka w strukturę gleby poprzez orkę może spowodować zasiedlenie uprawy przez większą grupę gatunków pająków, umożliwiając im dogodne miejsce do zakładania sieci, jak i zimowania (Duffey 1978; Frank i wsp. 2010; Gallé i wsp. 2018).

Diagram niemetrycznego skalowania wielowymiarowego (NMDS) wskazuje na podobieństwa i różnice w składzie gatunkowym i liczebności pająków na polach rzepaku w badanych systemach uprawy gleby (rys. 3). Wprawdzie wyróżnić tu można zbiór Araneae wspólny dla obydwu systemów uprawy niezależnie od roku badań, jednak widoczne jest tu także duże zróżnicowanie, które za pomocą analizy ANOSIM 
Tabela 1. Skład gatunkowy, liczebność i indeksy różnorodności pająków odłowionych w orkowej i bezorkowej uprawie rzepaku Table 1. Species composition, abundance and indices describing of spiders in ploughing and zero tillage rape cultivation

\begin{tabular}{|c|c|c|c|c|c|}
\hline \multirow{3}{*}{ Rodzina - Family } & \multirow{3}{*}{ Gatunek - Species } & \multicolumn{4}{|c|}{ Sposób uprawy gleby - Soil tillage } \\
\hline & & \multicolumn{2}{|c|}{ Bor $-\mathrm{Ni}$} & \multicolumn{2}{|c|}{$\mathrm{Or}-\mathrm{Pl}$} \\
\hline & & 2012 & 2013 & 2012 & 2013 \\
\hline Agelenidae & Agelena labyrinthica (Clerck, 1758) & 0 & 0 & 0 & 1 \\
\hline Liocranidae & Agroeca brunnea (Blackwall, 1833) & 0 & 0 & 0 & 2 \\
\hline Linyphiidae & Agyneta rurestris (C.L. Koch, 1836) & 0 & 1 & 0 & 0 \\
\hline Linyphiidae & Araeoncus humilis (Blackwall, 1841) & 2 & 0 & 0 & 0 \\
\hline Linyphiidae & Bathyphantes gracilis (Blackwall, 1841) & 2 & 5 & 2 & 0 \\
\hline Linyphiidae & Centromerus sylvaticus (Blackwall, 1841) & 0 & 1 & 0 & 0 \\
\hline Linyphiidae & Dicymbium nigrum brevisetosum Locket, 1962 & 0 & 3 & 0 & 0 \\
\hline Linyphiidae & Diplostyla concolor (Wider, 1834) & 3 & 0 & 0 & 0 \\
\hline Linyphiidae & Erigone atra Blackwall, 1833 & 52 & 13 & 9 & 5 \\
\hline Linyphiidae & Erigone dentipalpis (Wider, 1834) & 18 & 16 & 47 & 3 \\
\hline Mimetidae & Ero furcata (Villers, 1789) & 1 & 1 & 0 & 0 \\
\hline Hahniidae & Hahnia nava (Blackwall, 1841) & 0 & 3 & 0 & 0 \\
\hline Linyphiidae & Micrargus herbigradus (Blackwall, 1854) & 0 & 3 & 0 & 0 \\
\hline Linyphiidae & Microlinyphia pusilla (Sundevall, 1830) & 1 & 0 & 0 & 0 \\
\hline Linyphiidae & Oedothorax apicatus (Blackwall, 1850) & 145 & 146 & 118 & 154 \\
\hline Linyphiidae & Oedothorax fuscus (Blackwall, 1834) & 1 & 0 & 2 & 0 \\
\hline Linyphiidae & Oedothorax retusus (Westring, 1851) & 0 & 1 & 0 & 1 \\
\hline Tetragnathidae & Pachygnatha clercki Sundevall, 1823 & 0 & 3 & 0 & 0 \\
\hline Tetragnathidae & Pachygnatha degeeri Sundevall, 1830 & 0 & 12 & 0 & 2 \\
\hline Lycosidae & Pardosa agrestis (Westring, 1861) & 28 & 1 & 1 & 0 \\
\hline Lycosidae & Pardosa lugubris (Walckenaer, 1802) & 0 & 0 & 1 & 0 \\
\hline Lycosidae & Pardosa paludicola (Clerck, 1758) & 2 & 8 & 0 & 2 \\
\hline Lycosidae & Pardosa palustris (Linnaeus, 1758) & 1 & 1 & 4 & 0 \\
\hline Lycosidae & Pardosa prativaga (L. Koch, 1870) & 3 & 2 & 2 & 4 \\
\hline Lycosidae & Pardosa pullata (Clerck, 1758) & 2 & 0 & 1 & 0 \\
\hline Lycosidae & Pardosa riparia (C.L. Koch, 1833) & 0 & 0 & 1 & 6 \\
\hline Phrurolithidae & Phrurolithus festivus (C.L. Koch, 1835) & 0 & 0 & 0 & 1 \\
\hline Pisauridae & Pisaura mirabilis (Clerck, 1757) & 1 & 0 & 1 & 2 \\
\hline Linyphiidae & Porrhomma microphthalmum (O.P. Cambridge, 1871) & 0 & 0 & 0 & 1 \\
\hline Linyphiidae & Porrhomma pallidum Jackson, 1913 & 0 & 4 & 0 & 0 \\
\hline Linyphiidae & Porrhomma pygmaeum (Blackwall, 1834) & 0 & 0 & 1 & 0 \\
\hline Theridiidae & Robertus arundineti (O.P. Cambridge, 1871) & 0 & 5 & 0 & 1 \\
\hline Linyphiidae & Tallusia experta (O.P. Cambridge, 1871) & 0 & 3 & 0 & 0 \\
\hline Linyphiidae & Tiso vagans (Blackwall, 1834) & 0 & 0 & 0 & 2 \\
\hline Lycosidae & Trochosa ruricola (De Geer, 1778) & 0 & 3 & 1 & 6 \\
\hline Linyphiidae & Walckenaeria antica (Wider, 1834) & 0 & 1 & 0 & 0 \\
\hline Thomisidae & Xysticus cristatus (Clerck, 1758) & 0 & 1 & 0 & 0 \\
\hline Thomisidae & Xysticus kochi Thorell, 1872 & 0 & 4 & 0 & 0 \\
\hline \multicolumn{2}{|c|}{ Liczba osobników - Number of individuals } & 262 & 241 & 191 & 193 \\
\hline \multicolumn{2}{|c|}{ Liczba gatunków - Number of species } & 15 & 24 & 14 & 16 \\
\hline \multicolumn{2}{|c|}{ Różnorodność Shannona (H') - Shannon’s Diversity (H') } & 1,429 & 1,75 & 1,203 & 1,009 \\
\hline \multicolumn{2}{|c|}{ Równomierność Pielou (J') - Pielou evenness (J') } & 0,528 & 0,551 & 0,456 & 0,364 \\
\hline
\end{tabular}

Bor - bezorkowy - Ni - non-inversion, Or - orkowy - Pl - plough 

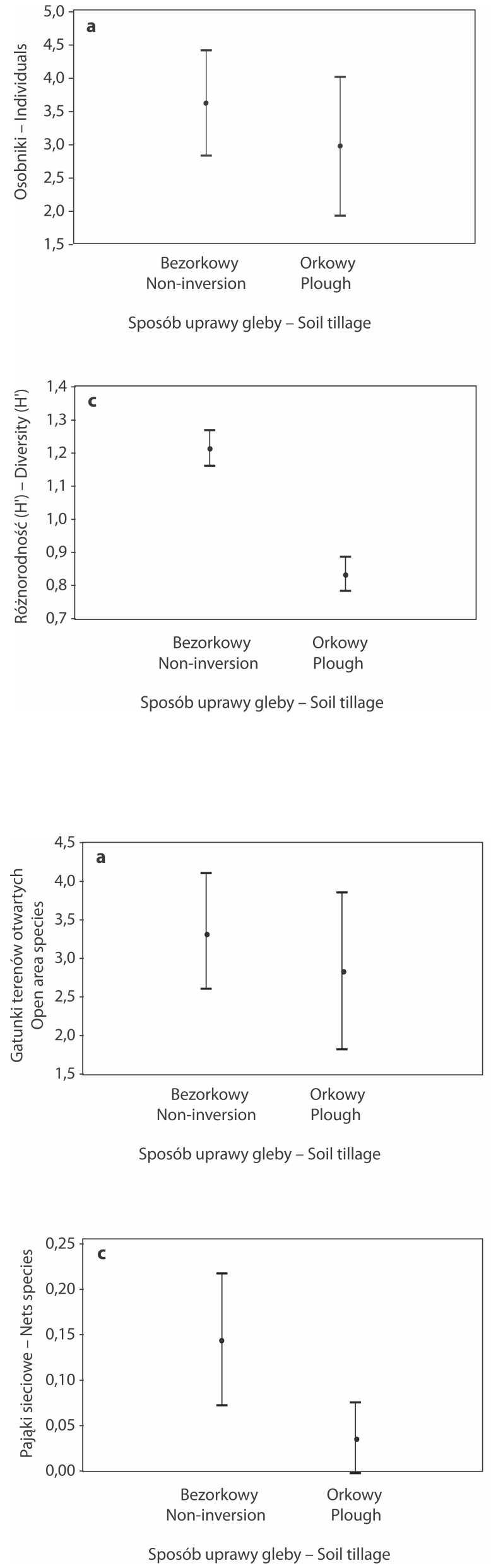

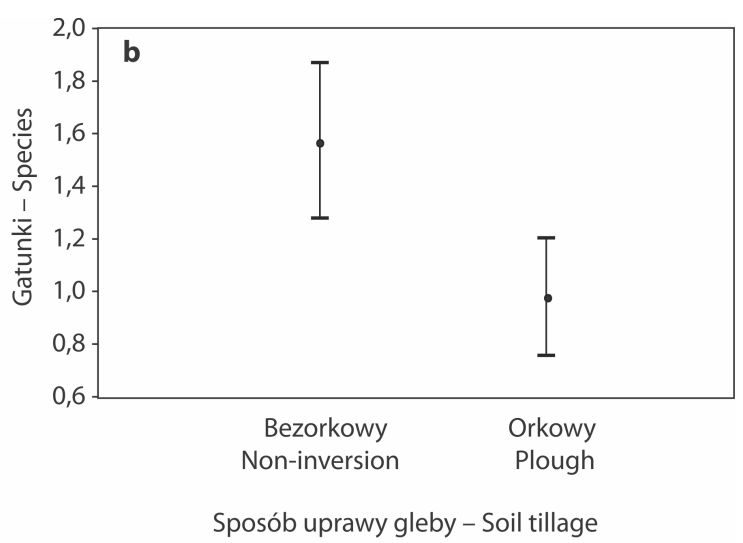

Rys. 1. Średnia liczebność (a), liczba gatunków (b) i wartość indeksu różnorodności (c) pająków występujących w uprawie rzepaku w zależności od systemu uprawy gleby (orkowy i bezorkowy). Pionowe linie wskazują 0,95 przedziału ufności

Fig. 1. Average abundance (a), number of species (b) and diversity (c) of spiders depended on studied soil tillage (ploughed and non-inversion) in studied rape cultivation. The vertical lines indicate 0.95 confidence interval

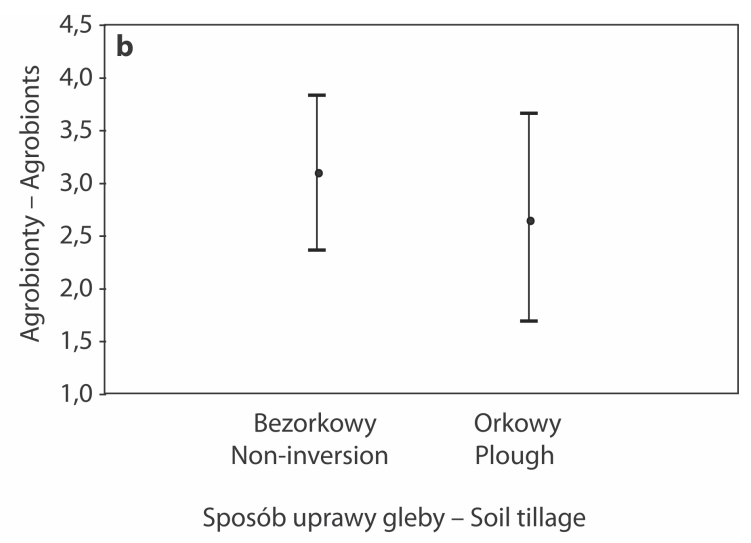

Rys. 2. Średnia liczebność pająków terenów otwartych (a), agrobiontów (b) i pająków sieciowych (c) występujących w uprawie rzepaku w zależności od systemu uprawy gleby (orkowy i bezorkowy). Pionowe linie wskazują 0,95 przedziału ufności

Fig. 2. Average abundance of open area spiders (a), agrobionts (b) and nets spiders (c) depended on studied soil tillage (ploughed and non-inversion) in studied rape cultivation. The vertical lines indicate 0.95 interval 


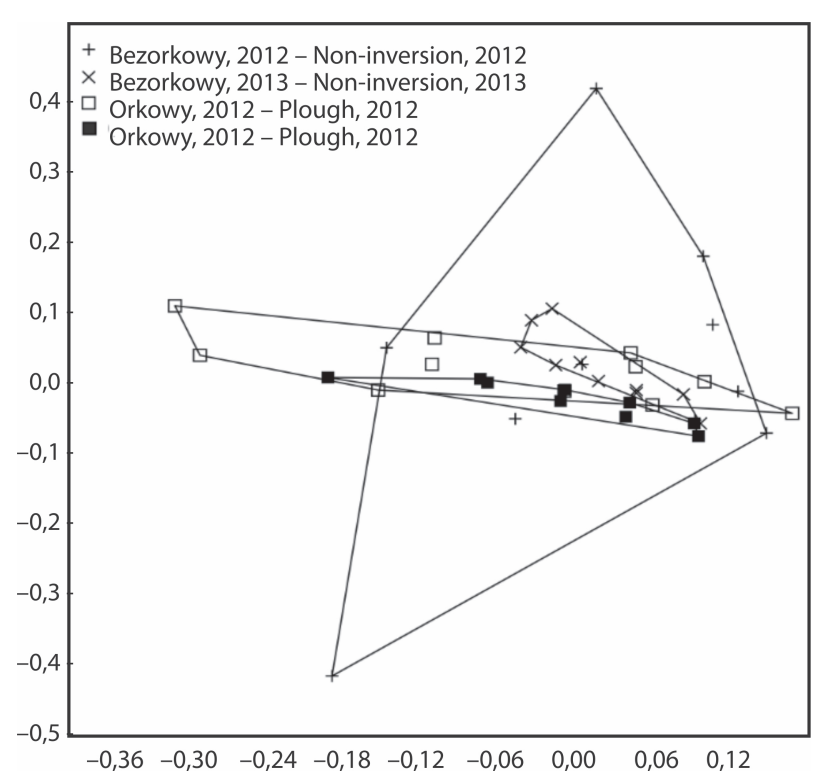

Rys. 3. Diagram niemetrycznego skalowania wielowymiarowego (NMDS) dla badanych zgrupowań pająków występujących w uprawie rzepaku ozimego

Fig. 3. Diagram of non-metric multidimensional scaling (NMDS) for studied spiders assemblages occurenced in the winter rape cultivation

zostało potwierdzone jako statystycznie istotne (R: 0,1375; p: 0,001). W roku 2013 to zróżnicowanie było mniejsze, natomiast rok 2012 charakteryzował się bardzo dużą zmiennością w obrębie badanych systemów uprawy gleby. Według autorów Samu i Szinetar (2000), Drapela i wsp. (2011) oraz Entling i wsp. (2011), pod wpływem zmian w strukturze gleby, np. spowodowanych przez orkę, zmienia się liczebność, skład gatunkowy, a także zachowania poszczególnych gatunków. Gatunki agrobiontyczne są charakterystyczne dla siedlisk uprawnych, i dostosowane do regularnych zakłóceń spowodowanych między innymi płużną uprawą gleby. Entling i wsp. (2011) podają, że pająki z zaburzonych siedlisk wzbijały się w powietrze w ilościach pięciokrotnie większych niż pająki z siedlisk stabilnych. Szczególnie odporny na te zakłócenia jest gatunek O. apicatus (Black.), jednakowo liczny w badanych kombinacjach, jak i latach obserwacji. Z kolei pająki z rodzaju Pardosa spp., również agrobiontyczne, wydają się bardziej wrażliwe na uprawki glebowe, a źródłem ich obecności na polach są najczęściej zadarnione miedze i brzegi pól oraz zadrzewienia śródpolne (Jõgar i wsp. 2004b; Topa i wsp. 2010; Gallé i wsp. 2018).

Uzyskane wyniki badań wskazują, że bezorkowy system uprawy gleby sprzyja występowaniu pająków, które jako
Tabela 2. Wyniki testu GLM (uogólnionego modelu liniowego) dla liczebności, liczby gatunków, różnorodności oraz wybranych parametrów życiowych pająków badanych pól

Table 2. Results of GLM (General Linnear Model) test of significance for abundance, number of species, diversity and some life traits of spiders in the studied fields

\begin{tabular}{l|c|c}
\hline \multicolumn{1}{c|}{ Efekt - Effect } & $\begin{array}{c}\text { Statystyki Walda } \\
\text { Wald's statistics }\end{array}$ & $p$ \\
\hline $\begin{array}{l}\text { Liczba osobników } \\
\text { Number of individuals }\end{array}$ & 8,35 & 0,004 \\
\hline $\begin{array}{l}\text { Liczba gatunków } \\
\text { Number of species }\end{array}$ & 17,82 & 0,000 \\
\hline $\begin{array}{l}\text { Różnorodność Shannona (H') } \\
\text { Shannon's diversity (H') }\end{array}$ & 9,02 & 0,002 \\
\hline $\begin{array}{l}\text { Generaliści } \\
\text { Generalists }\end{array}$ & 6,05 & 0,01 \\
\hline $\begin{array}{l}\text { Gatunki terenów otwartych } \\
\text { Open area species }\end{array}$ & 5,55 & 0,018 \\
\hline $\begin{array}{l}\text { Gatunki leśne } \\
\text { Forest species }\end{array}$ & 4,78 & 0,028 \\
\hline $\begin{array}{l}\text { Agrobionty } \\
\text { Agrobionts }\end{array}$ & 6,89 & 0,01 \\
\hline $\begin{array}{l}\text { Pająki sieciowe } \\
\text { Net spiders }\end{array}$ & & \multicolumn{2}{|c}{ n.s. } \\
\hline
\end{tabular}

n.s. - różnice nieistotne - not significant differences

niewyspecjalizowani drapieżcy, mogą uzupełniać pulę pożytecznej entomofauny regulując populacje owadów szkodliwych, co wpisuje się w wytyczne integrowanych metod produkcji i ochrony roślin.

\section{Wnioski / Conclusions}

1. Stosowanie uproszczeń $\mathrm{w}$ uprawie rzepaku ozimego w postaci uprawy bezorkowej wpłynęło na zwiększenie zarówno liczebności, jak i różnorodności gatunkowej pająków epigeicznych.

2. W obu wariantach uprawy gleby dominowały pająki z rodziny Linyphidae z najczęściej występującym gatunkiem O. apicatus (Black.) oraz pająki z rodziny Lycosidae z najliczniejszym gatunkiem $P$. agrestis (Westr.).

\section{Podziękowanie / Acknowledgements}

Składam serdeczne podziękowanie Pani dr Izabeli Hajdamowicz za pomoc w oznaczeniach arachnologicznych.

\section{Literatura / References}

Barber H.S. 1931. Traps for cave-inhabiting insects. Journal of the Elisha Mitchell Scientific Society 46 (2): $259-266$.

Büchs W., Felsmann D., Schlein O. 2007. Predators as biological control agents in winter oilseed rape fields - results on predators from the EU-Project MASTER. Proceedings of the 12th International Rapeseed Congress, Plant protection: Pests, Vol. 4: 280-283. 
Downie I.S., Ribera I., McCracken D.I., Wilson W.L., Foster G.N., Waterhouse A., Abernethy V.J., Murphy K.J. 2000. Modelling populations of Erigone atra and E. dentipalpis (Araneae: Linyphiidae) across an agricultural gradient in Scotland. Agriculture, Ecosystems and Environment 80 (1-2): 15-28. DOI: 10.1016/S0167-8809(00)00130-4

Drapela T., Frank T., Heer X., Moser D., Zaller J.G. 2011. Landscape structure affects activity density, body size and fecundity of Pardosa wolf spiders (Araneae: Lycosidae) in winter oilseed rape. European Journal of Entomology 108 (4): 609-614. DOI: 10.14411/ eje. 2011.079

Drapela T., Moser D., Zaller J.G., Frank T. 2008. Spider assemblages in winter oilseed rape affected by landscape and site factors. Ecography 31 (2): 254-262. DOI: 10.1111/j.0906-7590.2008.5250.x

Duffey E. 1978. Ecological strategies in spiders including some characteristics of species in pioneer and mature habitats. Symposia of the Zoological Society of London 42: 109-123.

Entling M.H., Stämpfli K., Ovaskainen O. 2011. Increased propensity for aerial dispersal in disturbed habitats due to intraspecific variation and species turnover. Oikos 120 (7): 1099-1109. DOI: 10.1111/j.1600-0706.2010.19186.x

Frank T., Drapela T., Moser D., Zaller J.G. 2010. Insect Pests and Spiders in Oilseed Rape and Their Response to Site and Landscape Factors. s. 285-304. W: Biocontrol-Based Integrated Management of Oilseed Rape Pests (I.H. Williams, red.). Springer, Netherlands, 461 ss. ISBN 978-90-481-3982-8. DOI: 10.1007/978-90-481-3983-5

Gallé R., Császár P., Makra T., Gallé-Szpisjak N., Ladányi Z., Torma A., Ingle K., Szilassi P. 2018. Small-scale agricultural landscapes promote spider and ground beetle densities by offering suitable overwintering sites. Landscape Ecology 33: 1435-1446. DOI: 10.1007/ s10980-018-0677-1

Hänggi A., Stoeckli E., Nentwig W. 1995. Habitats of Central European Spiders. Miscellanea Faunistica Helvetiae 4. Musée d'Histoire Naturelle de Neuchatel, 460 ss. ISBN 978-288-414-00-89

Holland J.M., Reynolds C.J.M. 2003. The impact of soil cultivation on arthropod (Coleoptera and Araneae) emergence on arable land. Pedobiologia 47 (2): 181-191. DOI: 10.1078/0031-4056-00181

Jõgar K., Metspalu L., Hiiesaar K. 2004a. Abudance and dynamics of wolf spiders (Lycosidae) in different plant communities. Agronomy Research 2 (2): 145-152.

Jõgar K., Võõbus H., Metspalu L., Hiiesaar K. 2004b. Spiders (Araneae) in summer oilseed rape, wheat and clover fields. Latvian Journal of Agronomy 7: 20-25.

Kosewska A. 2016. Conventional and non-inversion tillage systems as a factor causing changes in ground beetle (Col. Carabidae) assemblages in oilseed rape (Brassica napus) fields. Periodicum Biologorum 118 (3): 231-239. DOI: 10.18054/pb.2016.118.3.4074

Kosewska A. 2018. Porównanie zgrupowań biegaczowatych (Coleoptera, Carabidae) w orkowej i bezorkowej uprawie zbóż. [Comparison of ground beetle (Coleoptera, Carabidae) assemblages in tillage and no-tillage cultivation of cereals crop]. Progress in Plant Protection 58 (1): 40-48. DOI: 10.14199/ppp-2018-005

Nentwig W., Blick T., Gloor D., Hänggi A., Kropf C. 2020. Spiders of Europe. www.araneae.unibe.ch. [dostęp: 30.06.2020].

Nyffeler M., Sunderland K.D. 2003. Composition, abundance and pest control potential of spider communities in agroecosystems: a comparison of European and US studies. Agriculture Ecosystems and Environment 95 (2-3): 579-612. DOI: 10.1016/S0167-8809$-(02) 00181-0$

Öberg S., Cassel-Lundhagen A., Ekbom B. 2011. Pollen beetles are consumed by ground- and foliage-dwelling spiders in winter oilseed rape. Entomologia Experimentalis et Applicata 138 (3): 256-262. DOI: 10.1111/j.1570-7458.2011.01098.x

Piper R., Williams I. 2004. Incidence and feeding activity of epigeic, predatory invertebrates within winter oilseed rape in the UK with comparisons between integrated and conventional crop management. Integrated Protection in Oilseed Crops IOBC/WPRS Bulletin 27 (10): 281-288.

Samu F., Szinetár C. 2002. On the nature of agrobiont spiders. The Journal of Arachnology 30 (2): 389-402. DOI: 10.1636/0161-8202-(2002)030[0389:OTNOAS]2.0.CO;2

Schmidt M.H., Roschewitz I., Thies C., Tscharntke T. 2005. Differential effects of landscape and management on diversity and density of ground-dwelling farmland spiders. Journal of Applied Ecology 42 (2): 281-287. DOI: 10.1111/j.1365-2664.2005.01014.x

Sunderland K.D. 1999. Mechanisms underlying the effects of spiders on pests populations. The Journal of Arachnology 27 (1): $308-316$. DOI: $10.2307 / 3706002$

Symondson W.O.C., Sunderland K.D., Greenstone H.M. 2002. Can generalist predators be effective biocontrol agents? Annual Review of Entomology 47: 561-594. DOI: 10.1146/annurev.ento.47.091201.145240

Topa E., Sądej W., Bubienko K. 2010. Zadrzewienie śródpolne ostoją pająków Araneae w agrocenozie. [Field groves as refuge of spiders Araneae in agrocenosis]. Progress in Plant Protection/Postępy w Ochronie Roślin 50 (4): 2017-2023.

Twardowski J. 2010. Wpływ uproszczeń w uprawie roli pod pszenicę ozimą na zgrupowania stawonogów epigeicznych i glebowych. Monografia. Wydawnictwo Uniwersytetu Przyrodniczego we Wrocławiu, 141 ss. 